\title{
THE LEGAL AND TRADE EFFECT OF THE SAA BETWEEN THE REPUBLIC OF KOSOVO AND THE EUROPEAN UNION
}

\begin{abstract}
Burim Haliti
PhD candidate in Legal Sciences, South East European University, Tetovo, North Macedonia; Employer at Central Directorate of Customs of Kosovo, and is a member of the Board of the Institute for Legal and Democratic Studies, Kosovo

Tel.: +38344785857

burimhaliti@live.com

ABSTRACT

The Stabilization and Association Agreement with the Republic of Kosovo is a new chapter in the new institutional and social functioning because it has direct impact on the citizens' life in our country. The effects of the agreement are not only in trading but those are multiple effects, since they do touch the political stability, the rule of law, democratic governance, economic development, trade exchange, regional economic cooperation, etc. and therefore the relevance of this agreement should not be seen from a single viewpoint, but rather from a wider perspective and we should dedicate more attention to the direct legal and trading issues. This agreement in the short term will create perspective and hope, in the middle term, it will create political stability, whereas in the long term, it will bring economic development, and genuinely trading exchange.
\end{abstract}

Key words: effect, trading exchange, regional economic cooperation, political stability, Stabilization and Association Agreement. 


\section{INTRODUCTION}

The scientifical work represents a genuine reflection of the Stabilization and Association Agreement, and what it contains for the citizens' life in our country in the development plans in the next years. Through this work, the multiple effect of this agreement can be seen, but a more emphasized relevance should be dedicated for analyzing the legal, economic (trading), and political aspect of the agreement.

The Stabilization and Association Agreement touches many real aspects of life in Kosovo, but from the local aspect, it represents a permanent challenge until the consolidation of the implementing bodies of this agreement.

The legal effect of the agreement - it has a special feature, because the Republic of Kosovo is an equal party in relation to the member states of EU, and this agreement legally has a relevance in the context that it is not concluded with the EU as a whole (as other Balkan countries did), but with individual member states of the EU.

The trading effect of the agreement: it creates hope for the economic development of the country, by exchanging the products of Kosovo with the EU, and vice versa. In this context, the uniqueness lies on the fact that companies from Kosovo, legally, already have a market of selling goods to 500 million inhabitants, and henceforth the EU companies are considered as domestic companies in terms of the legal treatment of having the opportunity to cooperate with domestic companies and investing in our country.

Of course, the agreement presents a big challenge not only for the citizens of our country and our businesses; it is also a challenge for the institutions of the Republic of Kosovo, because they are responsible for the implementation, and for the control of the fictionalization of the common bodies and the mechanisms with the EU, and for finding budgetary fiscal alternatives to the lack of the customs revenues from the implementation of the SAA. That is why this makes us understand the obligatory planning and finding budgetary alternatives by national and international financial experts in covering the public expenses through alternative state incomes and having influence in: foreign investments in poor countries, market liberalization, opening the economy, legal security, Diaspora investments, benefits from international financial institutions, etc. 


\section{THE LEGAL EFFECT OF THE SAA BETWEEN THE REPUBLIC} OF KOSOVO AND THE EUROPEAN UNION

The legal effect of the SAA is very specific and characteristic, since the SAA is a legal document and represents an institutional challenge for the countries of the European Union, especially for the five countries that did not recognize the independence of our country, the Republic of Kosovo. The Stabilization and Association Agreement as a legal document represents the first legal report between the EU and the Republic of Kosovo, therefore as such it has a huge legal relevance, and it establishes implementing mechanisms and a new legal base in our country.

The Stabilization and Association Agreement between the Republic of Kosovo and the EU originates from 12 December 2012, when the Council for General Issues of the EU adopted the Commission's proposal for starting the negotiations, whereas on 28 June 2013 the Council of EU took the decision for starting the negotiations, and the first meeting was realized on 28 October 2013. The Republic of Kosovo and the European Union signed the Stabilization and Association Agreement on 27 October 2015, in Strasbourg. Then it was adopted by the Government of the Republic of Kosovo on 30 October 2015, through Decision no. 01/55 for adopting the draft proposal for ratification of the Stabilization and Association Agreement between Kosovo, as one party, and the European Union and the European Community for Atomic Energy, as the other party, and was ratified by the Assembly of the Republic of Kosovo on 2 November 2015, with the adoption of the Law no. 05/L-069 for ratification of the Stabilization and Association Agreement between Kosovo, as one party, and the European Union and the European Community for Atomic Energy, as the other party (Stabilization and Association Agreement, 2016).

Hereby, the bilateral agreement between the Republic of Kosovo and the EU was decided for having a legal association by assisting the Republic of Kosovo to improve in many institutional fields and segments, such as enhancing democracy, the rule of law, economic, political and regional stability, political dialogue, economic development and cooperation, national legislature, approximation of Kosovo with the legal acts of EU, facilitation of transition for getting on the market economy, etc. The agreement features that: "Association should develop in a progressive manner and should be fully realized during a ten year period" (Stabilization and Association Agreement, 2016). According to this provision, the full relations between the parties will be realized within a ten-year period, by stabilizing the market, and bringing the 
import/export taxes to the value of zero. The agreement considers that after this period, there will be a unique market between Kosovo and the EU, therefore as such it will gain a legal form only after the period of 10 years.

The structure of the Stabilization and Association Agreement as a legal act between the Republic of Kosovo and the EU is very polarized, since it consists:

Ten 'titles' (main chapters, or headings),

Seven appendices,

Five protocols and

A common statement" (Stabilization and Association Agreement (SAA), 2016).

In addition, this agreement envisions and has founded the bodies for monitoring the implementation and the real effects of this agreement as mechanisms that are responsible before the institutions of the Republic of Kosovo and the European Union:

- The Council for Stabilization and Association (the highest political level);

- The Stabilization Association Committee;

- The Stabilization Association Sub-committee;

- The Parliamentary Committee for Stabilization and Association (a common structure between the European Parliament and the Assembly of Kosovo). .

\section{THE TRADE RELEVANCE OF THE SAA BETWEEN KOSOVO AND THE EU}

The Stabilization and Association Agreement between the Republic of Kosovo and the European Union, besides its legal relevance, also has a relevance in the trade aspect because it challenges the domestic economy of Kosovo towards an economic superpower, as is the EU with its stable companies in the trade market.

The signing of the agreement represents a trade bravery of the Republic of Kosovo before the market of the EU, in the aspect of establishing trade relations between the two parties. The economy of Kosovo is gradually developing and is in the phase of finding stability in the domestic production, whereas companies in Kosovo are making attempts to overcome the initial problems of their work and assistance should be offered with the reformation of the tax and trade legislature of the country. 
Through the SAA, Kosovo has the chance to build a liberal economy, and based on the basic principle of competitiveness, companies in Kosovo are part of the competitiveness of the German, Italian or French sister companies. At this phase of the development of the companies in Kosovo, we can say that it is very difficult to face the European mega companies, since they already have fiscal endurance and long-term development planning.

The central relevance of signing this agreement in the trade aspect means a lot; if we have the ability and skill of good management in companies, then on the middle term we can see the effects and results of this agreement, whereas in the short term, this agreement for many companies, which are not standardized, can be a regress and have a negative impact on the entire economy of Kosovo. On the other hand, this agreement for the European companies has little relevance, since Kosovo's market is a lot smaller than the European market, so Kosovo's companies have the opportunity to benefit from this market.

\section{THE TRADE OBJECTIVES OF KOSOVO THROUGH THE SAA}

The trade relations between Kosovo and the EU are one of the main points of the SAA agreement, and that is why the creation of a free trading and economic zone is one of the key and basic challenges coming out of this agreement: "Promoting harmonized economic relations and gradually developing free trading zone between the EU and Kosovo" (Stabilization and Association Agreement, 2016).

According to the SAA, the creation of the trading zones is a precondition for promoting economic relations between the signing subjects of this agreement, and in this direction, we should be engaged in creating such trading mechanisms that will have an impact on creating preconditions for economic development.

\section{GRADUAL TRADE LIBERALIZATION OF THE MARKET OF KOSOVO FOR THE PRODUCTS OF EU}

The implementation of the SAA brings positive effects in the economic development of the country because it envisions the trade liberalization in Kosovo in relation to the products of EU, and this liberalization should occur through economic and trade reforms, encompassing both the public and private field. To carry out a basic reform in the field of economy, envisioned in the National Program for Implementing the Stabilization and Association Agreement (NPISAA), several reforms in a manner to increase the economic efficiency in offering services have been initiated: "The structural reforms have included the restructuration and 
privatization of some public services in order to increase the economic efficiency in offering services" (NPISAA, 2016).

The realization of reforms in this direction has an impact on the business and economic development, but service reforms refer to a new real and adequate potential in the economic development of the country.

Financial cooperation: Through the SAA, the European Union is obliged to assist Kosovo in the financial aspect by the European Investment Bank. The Republic of Kosovo receives financial assistance from the EU in the form of grants, loans, and should be orientated in realizing the democratic, economic, and institutional reforms. The financial assistance of EU is conditioned with the further progress in fulfilling the political criteria of Copenhagen (Stabilization and Association Agreement, 2016).

The financial assistance that comes from the EU in the form of the cooperation should be supported in the field of freedom, security and justice, approximation of the legislature with the acquis of the EU, socio-economic development, good governance, reforms in the public administration, energy, and agriculture.

Employment and competitiveness - Through this agreement, employment is stimulated if there is a good use of the resources by both signing parties, because the European companies will make investments in our country as a result of the economic parameters being in their interest since the labor force is cheaper, and the equity of the European companies with the domestic companies means that the procedures of doing business are the same for both parties, so the foreign investments represent a real opportunity for our country. This agreement also regulates that both signing parties have no right through other agreements and mechanisms to obstruct, limit or prevent competitiveness. The public companies offering public services are obliged within three years to respect the competitiveness rules and the Tractate for the work of EU, to the extent to not prevent the offering of these services.

\section{THE EFFECT OF THE SAA ON STATE INCOMES}

The effect of the SAA is not only of a political, legal, democratic, and economic nature and having impact on the security; it has also a valuable effect in the financial and budgetary aspect on the country. According to the SAA, all goods imported into the Republic of Kosovo will have the releasing preference of the customs tax of $10 \%$ and vice versa, gradually in the first 10 years of the implementation of the SAA, and after this period, the customs tax of $10 \%$ 
will be entirely removed, except for goods that are considered as strategic and necessary for both parties.

Based on the official data announced by the Customs of Kosovo, we can see that the implementation of the SAA has had sufficient impact on the state budget. Therefore, alternatives to this lack of state incomes should be created through various financial national and international projects, in order to lower the lack of the financial means. The budgetary effect in gathering the customs revenues can be seen from 1 April 2016, when the SAA legally entered into force, and had produced legal effects between the contracting parties: Kosovo and the EU.

The customs tax effect on the import was seen from 1 April 2016 until 31 December 2019, since the customs value of imported goods from the economic subjects of Kosovo with origin from the EU countries was above 2 billion euros, or exactly 2,214,732,977.37 euros. This trade exchange in importing goods with this customs base of 2,214,732,977.37 euros presents a customs tax of $10 \%$, so the value of $132,981,451.01$ euros should have been paid, whereas the VAT should have amounted to 22,838,049.12 euro. From the presented data, we can see that the unpaid customs tax and the VAT for goods originating from the EU, as a result of the Stabilization and Association Agreement, was over 150 million euros, or exactly 155,819,500.13 euros, based on the data announced by the Customs of Kosovo (The impact of SAA, 2020).

There was a high impact in gathering customs revenues from 1 January 2020 until 30 November 2020, since the customs base of the imported goods by the economic subjects of Kosovo originating from the EU countries was over 600 million euros or exactly $614,893,989,51$ euros. The value of the customs tax was over 50 million euros or exactly $52,012,523,17$ euros, and the value of the VAT was 8,837,723,25 euros from this customs base. In total, only for 11 months of 2020 (1 January - 30 November) the SAA had impact in gathering the customs revenues and the VAT at the borders, totaling about 60 million euros, or more precisely 60,850,246,42 euros (The impact of SAA, 2020).

The budgetary effect of the SAA from 1 April 2016 until 30 November 2020, was over 200 million euros, or exactly 207,832,023.30 euros. This shows that these means for this period were not added to the state budget because the SAA had effect on releasing the customs tax in a gradual manner, and not collecting the customs tax for goods originating from the EU countries imported into Kosovo. 
This shows the necessity for planning and finding budgetary alternatives by national and international financial experts in covering the public expenses through alternative state incomes having impact on foreign investments in our country, market liberalization, opening the economy, legal security, Diaspora investments, benefits from international financial institutions, etc.

\section{CONCLUSIONS}

The Stabilization and Association Agreement should be analyzed cleverly by experts and managers of institutions in order to achieve success and use the advantages of this agreement with the EU. The SAA besides its positive things has flaws and shortcomings, which we should try to eliminate.

The implementation of the agreements means having over 500 million inhabitants and having equity of Kosovo's companies with those in EU. The question that arises here is whether Kosovo's companies are ready and capable to resist the EU in the context of the competitiveness, taking into consideration their financial stability. Therefore, we should have worked three years before this agreement entering into force in consolidating and preparing our companies for the European trade market competitiveness.

It is not sufficient the EU business being equal in the legal aspect with Kosovo's businesses; there should be a simplification of the procurements for doing business and their functioning in order to get more investments by these companies, and increase the employment, and the internal economic development and production.

The lack of application of the export tax brings a risk that the entire domestic production can go out for the EU countries as a result of the economic interest, which presents a risk for the domestic consumption. Therefore, we should take measures so that our companies, working in production, are oriented and directed towards the domestic market or creating trade correlations with countries outside the EU, and in case there are such risks, we will have the chance to make it up for those products.

Based on the official data announced by the Customs of Kosovo, we can see that the implementation of the SAA had a big impact on the state budget. As a result of this lack of 
SEEU Review Volume 16 Issue 1

state incomes, we should create alternatives through various national and international financial projects, in a way to prevent the appearance of the lack of financial budgetary means.

This shows the necessity for planning and finding budgetary alternatives by national and international financial experts in covering the public expenses through alternative state incomes having impact on foreign investments in our country, market liberalization, opening the economy, legal security, Diaspora investments, benefits from international financial institutions, etc. 


\section{REFERENCES}

1. Marrëveshja e Stabilizim Asociimit. (2016, 04 01). (Qeveria e Republikës së Kosovës, Ed.) Gazeta Zyrtare e Republikës së Kosovës, nr. 34 (2015)(Neni 121, Titulli IX Bashkëpunimi financiar,), 47. Retrieved 12 24, 2020, from https://gzk.rks-gov.net/: https://gzk.rks-gov.net/ActDocumentDetail.aspx?ActID=11239

2. Marrëveshja e Stabilizim Asocimit. (2016, 04 01). (Qeveria e Republikës së Kosovës, Editor) Retrieved 12 14, 2020, from http://www.mei-ks.net/sq/procesi-i-stabilizimasociimit-78

3. Marrëveshja e Stabilizim Asocimit. (2016, 04 01). (Qeveria e Republikës së Kosovës, Ed.) Official Journal of the Republic of Kosovo,, No. 34 (2015)(See Article 9, paragraph 1,). Retrieved $12 \quad 20, \quad 2020$, from https://gzk.rksgov.net/ActDocumentDetail.aspx?ActID=11239

4. Ndikimi i MSA-së . (2020, 12 17). Dogana e Kosovës. (D. e. Kosovës, Editor) Retrieved 12 17, 2020, from https://dogana.rks-gov.net/: https://dogana.rksgov.net/per-doganen/statistikat-dhe-arritjet/ndikimi-i-msa-se/

5. Ndikimi i MSA-së. (2020, 12 17). (D. e. Kosovës, Editor) Retrieved 12 17, 2020, from https://dogana.rks-gov.net/per-doganen/statistikat-dhe-arritjet/ndikimi-i-msa-se/

6. NPISAA. (2016). National Program for the Implementation of the Stabilization and Association Agreement. Government of the Republic of Kosovo. Prishtina: Ministry of European Integration. Retrieved 12 20, 2020, from http://meiks.net/repository/docs/20190530072717_anglisht2016.pdf

7. Stabilisation and Association Agreement (SAA). (2016, 04 01). (O. J. Kosovo, Ed.) Official Journal of the Republic of Kosovo, no. 34 (2015), 01 - 321. Retrieved 12 20, 2020, from https://gzk.rks-gov.net/ActDocumentDetail.aspx?ActID=11239

8. Stabilisation and Association Agreement. (2016, 04 01). SAA. (O. J. Kosovo, Ed.) Official Journal of the Republic of Kosovo, no. 34 (2015)(Article 1, paragraph f). Retrieved $12 \quad 20, \quad 2020, \quad$ from https://gzk.rksgov.net/ActDocumentDetail.aspx?ActID=11239 